\title{
"Poética Histórica", Narrativa e Interpretação
} Ira Bashkar ${ }^{1}$, com tradução de Cid Vasconcelos ${ }^{2}$

${ }^{1}$ PhD em Cinema Studies pela New York University, em 2005. É professora de estudos de cinema na Jawaharlal Nehru University desde 2008, com diversas publicações na área, dentre elas essa, publicada originalmente em: (eds.) Stam, Robert; Miller; Toby. A Companion to Film Theory. Londres: Blackwell, 1999, pp.

${ }^{2}$ Cid Vasconcelo é vinculado ao Bacharelado de Cinema do Departamento de Comunicação Social da Universidade Federal de Pernambuco. 


\section{Resumo}

O artigo defende, embasado nas teorias de Mikhail Bakhtin, que a "poética histórica" pensada por Bordwell, ao se centrar efetivamente em aspectos formais e relativos ao modo de produção do cinema, constrói uma proposta neo-formalista, incapaz de se abrir para dimensões de sentido que as transcendem, pois são vinculadas a significações culturais e ideológicas incapazes de serem adequadamente contempladas pela método empregado pelo autor.

Palavras-chave: David Bordwell; Neo-Formalismo; Mikhail Bakhtin; Teoria do Cinema.

\section{Abstract}

This article through the ideas of Mikhail Bakhtin makes a criticism of "historical poetics" by Bordwell. Focusing in formal and mode of production matters, Bordwell is incapable to open his thinking to senses beyond both like those that could be built by cultural and ideological significations.

Keywords: David Bordwell; Neo-formalism; Mikhail Bakhtin; Cinema Studies. 
A literatura é uma parte inseparável da cultura e não pode ser compreendida fora do contexto total de uma cultura inteira de uma dada época.

Mikhail Bakhtin, "Resposta a um Questionário para o editorial de Novy Mir" (ênfase minha).

A interpretação toma como seu objeto básico nossos processos perceptuais, cognitivos e afetivos, mas o faz de modo indireto - atribuindo sua "produção" ao texto "de fora". Compreender um filme de modo interpretativo é submetê-lo aos nossos esquemas conceituais, e então dominá-los, ainda que tacitamente.

David Bordwell, Making meaning 
Em Making meaning, David Bordwell propõe o projeto de uma "poética histórica" como uma alternativa para uma reflexão sobre o cinema, dominada pela interpretação que, segundo o autor, tem sido infundada precisamente na atividade interpretativa que pode ser caracterizada por suas atribuições altamente suspeitas de sentidos implícitos e sintomáticos a um texto. ${ }^{1}$ Enquanto a maior parte dos acadêmicos não contestaria, antes saudaria, a chamada de Bordwell para uma contextualização histórica do cinema, existem diversos que não responderiam tão positivamente à sua caracterização da atividade interpretativa per se, a despeito

\footnotetext{
${ }^{1}$ No último capítulo de Making meaning, intitulado "Por que não ler um filme", Bordwell constata que "interpretar um filme é atribuir sentidos implícitos ou sintomáticos a ele" (1989b: 249). Aqui ele leva ao ápice sua crítica da interpretação e analisa se não é tempo de se considerar "o fim da interpretação". O autor faz várias recomendações para que se retifiquem o excesso de crítica interpretativa, e sente que as "questões de composição, função e efeito que a crítica interpretativa estabelece como resposta são endereçadas mais diretamente e melhor respondidas por uma poética do cinema auto-consciente e histórica", que ele define como "o estudo de como, em determinadas circunstâncias, filmes são agrupados, servem funções específicas e conquistam efeitos também específicos” (p. 266-7). Ele também discute o conceito no ensaio "Poética Histórica do Cinema" (1989a). Minha discussão sobre o conceito de "poética histórica" de Bordwell se baseia nesses dois textos. Entretanto, minha compreensão de "poética histórica" é condicionada pelas formulações de uma "poética histórica" e "sociológica" de Bakhtin e Medvedev em sua resposta e crítica ao formalismo russo. Embora suas "poéticas sociológicas" compartilhem muitas atitudes e recursos com o formalismo russo, incluindo a ênfase do último nos problemas da especificidade literária e a importância da compreensão das "funções construtivas de cada um dos elementos", estas criticam e são diretamente opostas à perda "do sentido semântico completo e do significado ideológico" que o formalismo russo observava como necessário para os elementos da obra adquirirem "significação construtiva". A poética "histórica" e "sociológica" de Bakthin e Medvedev, portanto, é comprometida a compreender a obra literária e artística no contexto da "unidade da literatura", que não pode ser compreendida fora da "unidade da vida ideológica", que por sua vez "não pode ser estudada à margem do complexo de leis de desenvolvimento sócio-econômico". Enquanto a formulação de "poética histórica" de Bordwell leva "as leis de desenvolvimento socioeconômico" da forma em questão, ignorando a conexão crucial e orgânica entre todas essas dimensões. De acordo com Bakhtin e Medvedev, a "história deve revelar a própria mecânica da etapa ideológica", consideração que Bordwell não pensa ser necessária, seja para o historiador das formas artísticas, seja para a crítica histórica. Para as formulações de Bordwell, ver Making meaning (1989b). Para as de Bakhtin e Medvedev, ver seu The formal method in literary scholarship (1978: 30-1, 45, 62, 49, 27, 20).
} 
dos excessos da interpretação sublinhados por ele. Maus exemplos de qualquer atividade não condenam a sua validade inerente. No entanto, as objeções de Bordwell à interpretação não funcionam ao nível da aplicação inadequada ou deslocada dos princípios interpretativos na crítica corrente. Antes, é a natureza fundamental da atividade interpretativa em si mesma que contabiliza por seu lugar central na prática crítica e previne outras indagações mais importantes, que Bordwell encontra dificuldade de aceitar ou endossar. Portanto, ainda que a crítica interpretativa fosse remodelada, não "deslocaria as atribuições de sentidos implícitos ou sintomáticos de sua centralidade na prática crítica" (Bordwell, 1989b: 263). O problema para Bordwell, portanto, parece residir na ideia de sentidos implícitos ou sintomáticos que a interpretação lida, em oposição ao sentido referencial e explícito que é domínio da compreensão.

Uma resposta adequada à hostilidade de Bordwell à prática interpretativa e a alternativa da "poética histórica" que ele sugere precisaria confrontar sua caracterização, tanto da interpretação quanto da empreitada da poética histórica, tendo em vista examinar seu valor intrínseco e se as duas são de fato tão inimigas como Bordwell crê que sejam. Essa não é uma perspectiva desqualificadora, no entanto. A despeito da retórica de hostilidade à interpretação do início ao final de Making meaning, existem pontos nos quais de fato ele constata que não gostaria de repudiar a interpretação por completo, mas antes alocá-la "dentro de uma compreensão histórica mais ampla" (p. 266). Neste caso, "dentro da moldura de uma poética, a interpretação [assumiria] sua própria importância” (p. 273). Ele também admite que as obras de Bazin, Burch e de alguns outros historiadorescríticos indicam que a "construção de sentido implícito e sintomático pode coexistir com o estudo da forma e do estilo em certas circunstâncias históricas" ( $p$. 267). Isso leva alguém a replicar que talvez o problema de Bordwell com a prática interpretativa seja que ela de fato não realiza seu potencial, não cumpre com o que é suposto a cumprir. No entanto, esse não é bem o caso. A despeito de sua tentativa de recuperar a interpretação dentro do domínio da "poética histórica" ao final de Making meaning, existe do início ao fim do livro uma suspeita que o leva a desconsiderar a significação da obra interpretativa per se que faz ele, de fato, 
pensar que possui algum valor. Existem, portanto, "ambiguidades não resolvidas e tensões", não somente, como Berys Gaut apontou, na noção chave da teoria neoformalista de Bordwell de construção (Gaut, 1995: 9) ${ }^{2}$, mas também de sua concepção do próprio projeto interpretativo.

Essas tensões e contradições na discussão da interpretação em Bordwell advêm da própria noção equívoca da empreitada em si. Além do mais, é propósito deste capítulo defender que a incompreensão de Bordwell sobre a interpretação advém de uma compreensão inadequada da narrativa e suas funções, efeitos e significados, e de uma compreensão incompleta da história. Bordwell observa uma forte divisão entre compreender a narrativa de um filme e interpretar seu sentido, assim como vê uma divisão entre sentidos referencial e explícita por um lado, e implícita e sintomática por outro. Existe uma cisma semelhante em Bordwell entre narrativa e ideologia, entre forma e conteúdo, e talvez também entre história e cultura. Na raiz dessas divisões reside a noção da narrativa como história ou "fábula" e sua apresentação como enredo ou "syuzhet". Construir a fábula a partir do syuzhet se torna uma atividade privilegiada da compreensão, os sentidos que são relevantes, de acordo com o autor, sendo aqueles vinculados a diegese da narrativa (referente) e sua "moral" ou "mensagem" explícita. Quaisquer outros tipos de sentidos que o crítico observe na narrativa são aqueles que ele traz de campos semânticos de instituições críticas que residem fora da narrativa. ${ }^{3}$

${ }^{2} \mathrm{O}$ argumento de Gaut neste artigo é que o neo-formalismo de Bordwell e Thompson é "grandemente falho". Enquanto Thompson e Bordwell não confrontam as tensões da noção central de construção em sua teoria, Gaut demonstra que os espectadores, em geral, não constroem os sentidos dos filmes. Há um papel limitado para a construção dentro de uma moldura detetivesca que é negligenciado por Bordwell e Thompson.

${ }^{3}$ Bordwell acredita que na atividade da compreensão, o receptor constrói o mundo textual, ou referencial, sentidos tanto diegéticos como explícitos, que possuem relação direta com a "mensagem" do texto. O receptor também constrói sentidos "encobertos, simbólicos ou implícitos" que podem ser identificados como "problemas" e "questões". Ele também constrói sentidos reprimidos ou sintomáticos "que a obra divulga 'involuntariamente"'. O sentido sintomático pode ser tratado como "consequência das obsessões do artista" ou tomado "como parte de uma dinâmica social" e 
A interpretação é, portanto, uma atividade suspeita para Bordwell porque é sempre efetivada às expensas de uma consideração da "forma e estilo" de um filme (1989b: 261), sendo o crítico interpretativo muito mais envolvido com as ideias teóricas abstratas do que com os princípios construtivos e os efeitos desses princípios.

Concebida nesses termos, a interpretação aparenta ser uma atividade estranha, já que tudo que é válido como uma resposta à narrativa é a compreensão - de seus sentidos referenciais e explícitos e, para além deles, de seus princípios construtivos e seus efeitos. Como poderia a "poética histórica" reformar a atividade da interpretação? Como Bordwell a define, a "poética histórica" parece muito mais preocupada em localizar elementos de estilo num determinado contexto histórico, estudando seu desenvolvimento histórico, os princípios construtivos dos filmes e seus efeitos, historicamente, do que com os sentidos que são centrais ao ato interpretativo. Compreender como o estilo cinematográfico se desenvolveu historicamente e quais os efeitos o cinema obteve em diferentes períodos históricos nos ajudaria a compreender o completo alcance de sentidos que um filme gera, e, assim, criaria interpretações melhores? As respostas ao problema-questões centrais que a poética histórica neoformalista se indagaria certamente aumentaria o nosso conhecimento de quais "opções construtivas" os realizadores enfrentariam em diferentes "conjunturas históricas" (Bordwell, 1989a: 381), e que impactos essas escolhas teriam em diferentes públicos em diferentes períodos. Porém para se compreender porque existiam certas escolhas diante dos realizadores e porque geraram certos efeitos em certos públicos, à parte da história de estilos, conceitos e determinações dos sistemas econômico e tecnológico que Bordwell enfatiza, também deveríamos

"vinculado aos processos econômico, político ou ideológico." Sentidos implícitos ou sintomáticos são o domínio da interpretação. Para essas definições, cf. Bordwell, 1989b: 8-9. Para uma discussão sobre a noção de narrativa de Bordwell e seu modelo construtivista de compreensão narrativa, cf. Bordwell, 1985: part. 29-62. Para uma discussão dos diferentes tipos de sentido e a atividade de interpretação, cf. Bordwell, 1989: particularmente 1-42;105-45. 
olhar para um campo inteiro da vida sociocultural que gera o que Bakhtin e Medvedev chamam de "horizonte ideológico" de uma época (1978: 17), a matriz determinante de todas as formas representacionais da época como também as respostas a essas formas. A visão de Bakhtin e Medvedev de que "o desenvolvimento qualitativo da existência e o mundo ideológico que é história [era] completamente inacessível ao formalismo" (p. 97) pode ser aplicada em parte, igualmente, à formulação de Bordwell da "poética histórica". É um tanto triste que Bordwell não leve em conta a inteira crítica bakhtniana do formalismo: ainda que ele leve em conta o que Bakhtin e Medvedev chamariam "a unidade da literatura" e as "leis unificadas de desenvolvimento socioeconômico", é o link perdido da "unidade da vida ideológica e histórica" do paradigma bakhtiniano 4 que torna a caracterização da história de Bordwell em sua "poética histórica" inadequada. Tivesse ele tomado conhecimento da formulação da "poética histórica" ${ }^{5}$ de Bakhtin, teria se tornado capaz de confrontar e entrar em um

\footnotetext{
${ }^{4}$ Bakhtin e Medvedev sentem que "a obra não pode ser compreendida fora da unidade da literatura (...) Porém esse todo não pode ser compreendido fora da unidade da vida ideológica. E essa última unidade (...) não pode ser estudada fora das leis comuns de desenvolvimento socioeconômico" (1978: 27).

${ }^{5}$ É intrigante que Bordwell não se refira a Bakhtin em nenhum dos dois textos nos quais define e discute a "poética histórica", particularmente quando se leva em conta que uma de suas críticas mais contundentes contra a "Grande Teoria" dos teóricos SLAB (aqueles que empregam princípios baseados na semiótica sausurreana, na psicanálise lacaniana, no marxismo althusseriano e na teoria textual barthesiana, e aqueles cuja obra Bordwell denomina "acronimicamente e um pouco acrimoniosamente, teoria SLAB" é que não fizeram "o dever de casa na história dos conceitos [dos autores em questão,] e que seu próprio relato da história da crítica em Making meaning é rigorosamente histórica. Cf. Bordwell, 1989a: 385, 388 e Bordwell 1989b: cap. 4, respectivamente. Na sua crítica ao formalismo russo, Bakhtin propõe como corretivo uma "poética sociológica" da arte como "poética histórica" enquanto corolário necessário. De acordo com os autores, a distinção entre uma "poética teórica sociológica" e uma "poética histórica" é "mais técnica que de natureza metodológica. E a poética teórica necessita ser histórica". Que as duas sejam fortemente imbricadas é óbvio no desenvolvimento de suas formulações ao longo do livro, mesmo que tenham considerado de maneira evidente que "o papel da poética histórica é preparar a perspectiva histórica para as definições generalizantes e sintéticas da poética sociológica". Podemos, portanto, assumir que os
} 
diálogo/debate com a última, que poderia levá-lo a uma noção de história mais compreensiva, certamente benéfica ao projeto de "poética histórica" que Bordwell propõe para revitalizar o campo dos estudos de cinema.

As respostas às questões referentes aos "princípios construtivos", funções e efeitos do cinema que a "poética histórica" de Bordwell propõe nos ajudam na compreensão dos sentidos de um texto fílmico - mesmo os sentidos referenciais e explícitos que Bordwell acredita que valham a pena? Não inteiramente, já que as implicações referenciais ou diegéticas e as mensagens explícitas ou morais do texto fílmico formam o conteúdo, que reflete, em termos bakhtinianos, "o todo do horizonte ideológico" do qual a literatura ou o cinema são, em si, uma parte (Bakhtin e Medvedev, 1978: 17). E se o conteúdo é gerado pelo ambiente ideológico de um determinado período, então os sentidos implícitos e sintomáticos poderiam ser contidos dentro deles, tanto quanto os referenciais e explícitos. E não são apenas os sentidos sintomáticos que podem ser traçados, como Bordwell diz, em "relação aos processos econômicos, políticos e ideológicos" (1989b, ver também nota 3), porém todos os tipos de sentido que estão contidos tanto no conteúdo quanto na forma da obra. Se seguirmos Bakhtin, forma e estrutura são tão ideologicamente conformadas quanto temas e conteúdo. ${ }^{6}$ Compreendida dessa maneira, a atividade interpretativa deve confrontar os sentidos de um texto e teria que lidar com a narrativa em mãos de

interesses sociais, culturais e ideológicos da "poética sociológica" modulados com uma perspectiva histórica seriam centrais a uma "poética histórica" como concebida por Bakhtin e Medvedev. Cf. The Formal Method (1978: 30-1) para as definições. Que Bakhtin tenha consistentemente se interessado por uma "poética histórica" da literatura, reflete-se igualmente em outra obra sua. Seu ensaio "Forms of time and of the chronotope in the novel" possui como subtítulo "Notes toward a historical poetics", onde tenta "uma evolução da forma a ser definida". Cf. respectivamente Bakhtin 1994: 84 e Bakhtin e Medvedev, 1978: 31. O sentido de história bakhtiniano, portanto, refere-se não somente ao tempo e contexto contemporâneos, mas a um inteiro peso do passado enquanto reverberadores num texto tanto formal como tematicamente.

"Bakhtin e Medvedev falam do "sentido profundamente ideológico da própria forma" e apontam para o enredo como "uma fórmula de vida refratada ideologicamente" com sua estrutura em forma de "valores ideológicos" (1978: 49, 17). 
forma direta, e não da forma "desviada" que Bordwell descreve. ${ }^{7}$

No entanto, isso demanda uma visão da narrativa como enraizada cultural e historicamente, incorporando dentro dela o mundo da vida de sua época: em outras palavras, incorporando as formas de vida cultural, processos, ideologias, valores, esquemas conceituais bastante complexos que Bordwell observa como objetos da interpretação. Se a narrativa fosse compreendida desta maneira, como codificação dentro de sua fábula e syuzhet, sua forma e estilo, a visão de seu mundo, então o ato interpretativo não seria esquematicamente separado do compreensivo e sentidos explícitos e referenciais carregariam dentro deles os implícitos e sintomáticos. A interpretação não seria vista como lidando com o texto de forma "desviada" ao atribuir aos nossos "processos perceptivos, cognitivos e afetivos" um objeto "exterior" (Bordewell, 1989b: 257), mas, antes, tornaria possível observar a interpretação como confrontando o texto muito mais diretamente de forma empática, exploratória e compreensiva. A "compreensão"8 resultante de um texto narrativo seria assim implicada numa compreensão tanto histórica quanto cultural do mundo, que tem produzido a narrativa, e daquele que ela representa. A resposta do leitor/espectador à narrativa dinamizaria seus

7 "A interpretação toma como nosso objeto básico nossos processos perceptivos, cognitivos e afetivos, mas o faz de forma desviada - atribuindo a sua 'produção' ao texto que se 'encontra fora'" (Bordwell, 1989b: 259).

${ }^{8}$ Bordwell admite que o objetivo da interpretação não é produzir "conhecimento" como as ciências naturais e sociais fazem, mas antes produzir "compreensão (verstehen)", que pode ser efetuada "através de uma especulação mais ou menos disciplinada sobre as possibilidades de sentido". Em sentido oposto à interpretação, o objetivo da poética histórica é produzir "conhecimento" e, portanto, outras "questões centradas" sobre a "composição" do filme, e seus "efeitos" e "funções" sendo importantes (Bordwell 1989b: 258, 263). Ao longo de toda a discussão da interpretação e da crítica histórica de Bordwell existe uma tensão entre "compreensão" e "conhecimento". E a polarização das duas não é tão problemática quanto a de interpretação e compreensão enquanto distintos gêneros de sentido? A asserção de Bordwell de que a poética histórica produzirá conhecimento como as ciências naturais e sociais fazem, e sua constante ênfase em ser científico, talvez compreenda equivocadamente os objetivos e pretensões das artes. Entretanto, essa questão se encontra fora do escopo desse capítulo. 
processos "perceptivos, cognitivos e afetivos", e o ato de interpretação diria respeito, então, à compreensão tanto do texto quanto a compreensão de nossos esquemas conceituais e nossa localização temporal num mundo que pode ou não ser similar ao do texto. A interpretação, portanto, é uma atividade de frente dupla - dirigida tanto para fora do texto e seu universo quanto para dentro de nós próprios e de nosso contexto, num movimento mutuamente elucidativo.

O que se discute aqui é uma concepção de narrativa que se encontra implícita na discussão do fazer sentido para Bordwell. Ela pode ser identificada com a teorização de Genette da narrativa como "discurso narrativo", em que sua definição e suas distinções dos três diferentes sentidos do termo compreendem a linguagem ou os meios de expressão, a história ou conteúdo e o ato de enunciação ou narração (Genette, 1993: 25-6). Embora Genette assinale que a análise do discurso narrativo "implique uma análise das relações", e que descrever qualquer um dos três aspectos da narrativa necessariamente envolve os outros (27-9), não localiza as três dimensões da narrativa na cultura. Sem a contextualização cultural e histórica, a análise do discurso narrativo pode se tornar apenas a exposição sobre 0 ato de enunciação, o sentido da narração ou expressão, e quando lidar com a história ou conteúdo como um todo pode encarar os problemas do autor ou da crítica temática descontextualizados - falta que Bordwell corretamente relaciona ao excesso de crítica explicativa. ${ }^{9}$

Contra a teoria da narrativa de Genette, é possível justapor a ideia bakhtniana de um texto narrativo como situado em uma matriz cultural discursiva que a penetra e manifesta a si própria em conteúdos e significados tanto óbvios quanto latentes. Da perspectiva bakhtiniana, um texto narrativo não pode ser compreendido sem uma decodificação dos sentidos culturais dos quais está imbuído, acumulados ao longo dos séculos, no estrato das linguagens populares, nas formas de manifestação cultural e nas "formas de pensamento" que são

\footnotetext{
${ }^{9}$ A crítica que lida especificamente com os sentidos "implícitos" de um texto. Ver Bordwell, 1989b: Capítulo 3.
} 
específicas a uma cultura particular ${ }^{10}$ e que o texto teceu em padrões de significação cultural (Bakhtin, 1986b: 5). ${ }^{11} \mathrm{~A}$ "compreensão narrativa" seria, portanto, compreender como a forma de uma obra particular incorpora as "formas de pensamento" que são específicas de uma cultura particular. E os sentidos "referenciais e explícitos" bordwellianos de um texto são, na verdade, formas de expressão cultural que carregam "sentidos implícitos e sintomáticos" que dão voz "às correntes culturais efetivamente profundas" (Idem: 3 ).

Isso não sugere, porém, que os sentidos sejam fixos para sempre e que a experiência do público não tenha um papel na construção do sentido, mas quaisquer que sejam as orientações que os públicos deem aos textos, ainda devem negociar seus "sentidos culturais", pois, como Bakhtin aponta, cada elocução é um ato histórico e social e uma "conexão orgânica, histórica e efetiva entre $\circ$ sentido e $\circ$ ato (elocução), entre $\circ$ ato e a situação sócio-histórica concreta" (Bakhtin e Medvedev, 1978: 120). Uma poética histórica deve, portanto, confrontar o contexto histórico da elocução com todos os significados que isso implica. Uma resposta bakhtiniana demandaria não somente uma localização contextual dos textos, que Bordwell não enfatiza adequadamente, mas também uma localização contextual do público para o qual ele volta sua atenção em sua proposta que, desde a poética históric,a diz respeito aos "efeitos" e estudará as "práticas [...] de recepção" assim como as de "produção" (1989b: 270). Enquanto as situações históricas e sociais se transformam, existem várias interpretações

\footnotetext{
${ }^{10}$ Bakhtin considera que "é impossível compreender a elocução sem lidar com seus valores, sem compreender a orientação de suas evoluções no ambiente ideológico" (Bakhtin e Medvedev, 1978: 121). Utilizar a sugestão bakhtiniana facilitaria um confronto entre as ressonâncias históricas e culturais de um texto e preveniria o tipo de interpretações selvagens que pouco tem a ver com o texto porque estão muito mais intrinsecamente envolvidas em realizar hipóteses das teorias ou instituições críticas que as produzirem, e que Bordwell acertadamente condena.

${ }^{11}$ Para uma compreensão das ideias de Bakthin sobre o dialogismo e a relação texto-contexto, fiz uso de Bakhtin 1986b, Bakhtin e Medvedev 1978, Stam 1989 e a seção sobre intertextualidade em Stam et al, 1992: 203-6. A utilização de Bakhtin por Robert Stam em sua crítica a cine-semiologia de Metz aguçou meus próprios argumentos contra o formalismo bordwelliano. Ver Stam, 1989: capítulo 1.
} 
que se tornam possíveis em contextos outros que aqueles nos quais os textos haviam sido produzidos, por conta da emergência e desenvolvimento de novos discursos e formulações teóricas que, como Bordwell corretamente apontou, formam a interpretação dos críticos. No entanto, o que Bordwell parece não aceitar é que a moldura institucional é somente um dos elementos determinantes do processo de elaboração de intepretações que formaria a outra importante dimensão do posicionamento leitor/espectador em sua ativa "interação" entre o texto e o receptor. Bakhtin, de fato, considera que a "obra nunca é uma mensagem dada de uma vez por todas", mas antes construída como uma "espécie de ponte ideológica" na interação entre o autor e o leitor, e que esse processo "provoca a unidade temática do trabalho geracional e o modo como ela se realiza de fato" (Bakhtin e Medvedev, 1978: 151-52). Utilizando a perspectiva bakhtiniana, portanto, seria possível evitar o tipo de problema que a narrativa construtivista de Bordwell pretende superar, qual seja, que os sentidos dos textos variam histórica e culturalmente - portanto, justificando sua defesa da construção de sentido como dependente das molduras que espectadores/leitores trazem aos textos, mais do que as encontram nos próprios textos. Em contraposição, o que a perspectiva bakhtiniana sugeriria é que embora leitores/espectadores tragam suas consciência política e cultural constituída fora do texto para a experiência literária/fílmica, flexionando-a, assim, com suas várias "linguagens perspectivas"12, eles ainda devem negociar o "horizonte ideológico" do texto - e, nessa interação, os "sentidos" que são justificáveis são aqueles que devem alguma fidelidade a características, estruturas e intenções textuais. Noutras palavras, as molduras teóricas extrínsecas que Bordwell afirma que os críticos

\footnotetext{
${ }^{12}$ Robert Stam considera que a "noção bakhtiniana de heteroglossia, enquanto diversas perspectivas de linguagem geradas pelas diferenças sexuais, raciais, econômicas e geracionais, é eminentemente compatível com as abordagens orientadas ao espectador." Enquanto tanto Bakhtin quanto teóricos posteriores da recepção "se encontrariam a favor da multiplicidade de posições espectatoriais, algumas vezes co-existindo dentro de um dado espectador", Stam também considera que o espectador é "historicamente situado (...) tanto no sentido biográfico quanto mais amplamente histórico" (1989: 43).
} 
utilizam para interpretar filmes somente se tornariam relevantes na interação textopúblico se existissem elementos no texto que respondam a eles. Isso quer dizer: a interação público-texto fílmico ainda funciona dentro de limites - limites impostos tanto por características textuais quanto por condições e condicionamentos históricos e culturais.

Lido dessa forma, compreender uma narrativa significaria não somente entender como as histórias são construídas e os efeitos que provocam nas pessoas, apesar de certamente implicarem isso. Também significaria compreender por que possuem tal efeito, o que nos traria face a face com as mensagens, tanto abertas como encobertas, que as narrativas levam mensagens que são "poderosas" e evocativas porque tocam em um substrato mais profundo de cordas numa cultura que, uma vez tocada, ressoa com a multiplicidade de implicações que a interpretação articula. Compreensão e interpretação estão, portanto, grandemente imbricadas, precisamente porque os sentidos com que elas lidam não podem ser separados de forma esquemática. Essa imbricação do que Bordwell chama de sentidos referencial, explícito, implícito e sintomático poderia talvez ser melhor compreendida se fosse feito uso da ideia barthesiana do funcionamento integrado dos cinco códigos ou vozes que o texto narrativo compreende. Enquanto os códigos proairéticos e hermenêuticos lidam com o enigma central e as ações das narrativas, os códigos sêmicos, simbólicos, culturais e referenciais estão preocupados e são, portanto, envolvidos com os sentidos que a cultura articula através desses textos (Barthes, 1994). Os códigos sêmicos articulam as associações culturais e emocionais de uma palavra/imagem e podem, portanto, ser vistos como contextualizados no referencial. O simbólico é, de acordo com Barthes, a "província da antítese" (p. 17) que orquestra a oposição da narrativa. Essas oposições são culturalmente determinadas e o jogo do simbólico negocia as antinomias através dos quais os sentidos culturais são articulados. Todos os cinco códigos são delimitados pelo forte peso da tradição - séculos do que Barthes chama "o que já foi escrito e feito" (Lesage, 1985: 478). A noção bakhtiniana de dialogismo como "a relação necessária de uma elocução com outras elocuções" (citado por Stam et al, 1992: 
203) que são enraizadas na vida e história socioculturais pode, portanto, ser relacionada ao sentido de Barthes de "que ao longo de cada elocução (...) vozes fora do palco podem ser ouvidas", vozes que podem ser entrelaçadas juntamente no texto e, portanto, incorporar "a pluralidade e a circularidade dos códigos" (1994:77). O paradigma bakhtiniano-barthesiano é um contra-movimento importante na prática de se ler a narrativa como "discurso narrativo", formulação que Bordwell implicitamente se identifica e simpatiza. Se a antiga formulação de narrativa foi utilizada para compreender os impulsos da ação interpretativa, as tensões e contradições na resposta de Bordwell à interpretação poderiam ser facilmente resolvidas, e seria possível ter uma contextualização da interpretação histórica e cultural, sem a qual nenhuma "poética histórica" de uma arte narrativa ou do cinema é compreendida ou adequada.

II

Uma chamada para restabelecer, juntamente com Bakhtin, o modelo de construção e interpretação narrativa barthesiana, deve, entretanto, levar em conta o fato que Bordwell rejeita tanto os modelos da comunicação (bakhtiniana) e da significação (saussureana) do sentido em favor do modelo inferencial através do qual o receptor faz uso de hipóteses no filme "para executar operações determináveis, das quais a construção de todos os tipos de sentidos fará parte" (Bordwell, 1989b: 270). Bordwell não analisa ou debate os valores e desvantagens dos dois modelos que rejeita, e nem tampouco a coerência interna do modelo inferencial que abraça. Sua formulação de uma poética neo-formalista que repousa em um modelo inferencial onde os sentidos são construídos pelos espectadores, aplicando esquemas a hipóteses sobre o filme, contradiz inerentemente o esquema explanatório do agente racional do filme, proposto pelo neo-formalismo, que destaca o controle voluntário sobre os sentidos de um filme efetivado por seu realizador, demonstrado nas escolhas de construção deliberadas que ele ou sua equipe efetivam durante o processo de filmagem ( $p$. 270). 
Se os sentidos são construídos pelos realizadores, como o modelo do agente racional de cinema implica, então como essa posição pode ser reconciliada com o modelo inferencial, em sintonia com o que Bordwell afirma ao longo de Making meaning, onde diz que "os sentidos não são encontrados, mas construídos" ( $p$. 3)? Se é verdade que Bordwell faz uso do modelo do agente racional para explicar a construção dos filmes e o modelo perceptivo-cognitivo ou inferencial de explicar os "efeitos" dos filmes, ele considera que "em alguma medida, o realizador (...) pode construir o filme de uma forma que certas hipóteses são suscetíveis de serem salientadas e certas trilhas inferenciais são ressaltadas." Entretanto, ele assegura muito corretamente que o realizador não pode controlar "todos os campos semânticos, heurísticos e esquemas que o receptor pode trazer para o filme" e, portanto, as plateias podem "utilizar o filme para outros propósitos que o realizador antecipou." Além do que, ele considera que críticos operando dentro da "instituição da crítica cinematográfica" são suscetíveis de "produzir sentidos implícitos e sintomáticos, independentemente das intenções do cineasta" (p. 270). Ainda que seja verdade que espectadores/leitores e críticos tragam ao texto significados que podem não ter sido pretendidos, Bordwell não enfatiza adequadamente que espectadores/críticos frequentemente tentam situar suas leituras em uma situação contextual que não somente leva em consideração as escolhas construtivas dos artistas, mas também as localiza em um contexto mais amplo que justifica o motivo destas escolhas terem sido necessárias. ${ }^{13} \mathrm{O}$ modelo inferencial que Bordwell utiliza para explicar a recepção necessita tanto do modelo do agente racional quanto do modelo institucional ${ }^{14}$, tanto quanto precisa de uma

\footnotetext{
${ }^{13}$ Isso pode variar das condições espectatoriais de produção, com as quais podem se encontrar familiarizados através da circulação do discurso jornalístico, até o tipo de crítica mais acadêmica que sofre para pesquisar os tipos de detalhes que o próprio Bordwell sugere que a boa crítica deveria fazer (1989b: 263).

${ }^{14}$ Bordwell aponta que o neo-formalismo baseia-se em três esquemas explanatórios: um modelo de agente racional, um modelo institucional e um modelo cognitivo-perceptivo. Ele explica o modelo institucional como o "sistema socioeconômico de produção, envolvendo concepções estéticas tácitas,
} 
contextualização sociocultural mais ampla se quiser explicar adequadamente por que os filmes provocam os efeitos que provocam. Ao utilizar diferentes modelos para explicar diferentes aspectos da filmagem e recepção sem enfatizar as interações entre os processos, ele somente destaca conclusões contraditórias: por exemplo, que os artistas controlam voluntariamente os sentidos com os quais traduzem suas escolhas construtivas por um lado, e que os públicos constroem os próprios sentidos que não encontram nos textos que recebem, por outro. Essas contradições em suas considerações sobre a construção de sentido, que Bordwell nem confronta nem resolve, poderiam ser efetivadas se as considerações bakhtinianas de recepção discutidas acima pudessem ser incorporadas no esquema de Bordwell. O resultado poderia ser uma "poética histórica" com interpretações verdadeiramente absorventes dentro dela, como Bordwell deseja.

O modelo inferencial de Bordwell, que motiva sua teoria da compreensão narrativa, tem sido criticado por Richard Allen, que demonstra que o uso da teoria cognitiva da percepção, na qual a teoria da compreensão narrativa de Bordwell é baseada, compreende mal a natureza do olhar, e não é uma explicação adequada para a compreensão da narrativa (Allen, 1997) ${ }^{15}$. Berys Gaut provou que o construtivismo do modelo inferencial de Bordwell é seriamente falho e não explica

a divisão do trabalho e procedimentos tecnológicos [que] formam o horizonte do que é permitido ou encorajado em momentos particulares." (1989a: 382-3).

${ }^{15}$ Allen aponta que a teoria cognitiva da percepção compreende mal a natureza do olhar, "já que a percepção não pode ser definida como um processo inferencial apesar de algumas formas de olhar envolverem inferências de sentido, quer dizer, um detetive tentando interpretar o que vê [...] no entanto, um filme não pode ser concebido como algo que torna explícito um processo inferencial que se encontra implícito ao olhar cotidiano, como a teoria defende." Allen também aponta que a compreensão e a interpretação das narrativas não podem ser tão bem divididas como Bordwell estabelece: "Ao compreender equivocamente a compreensão narrativa como um processo objetivo (baseado numa teoria do olhar equivocada), Bordwell extrai uma distinção errônea entre compreensão e interpretação da narrativa que soam como o toque do clarim para abandonar a atividade da intepretação em Making meaning" (do resumo de um artigo não publicado apresentado numa conferência). Sou grato a Richard Allen por compartilhar suas ideias comigo. 
a compreensão e interpretação dos filmes (Gaut, 1995). ${ }^{16}$ Portanto, ainda que Bordwell possa ter rejeitado a comunicação e a significação dos modelos semióticos por conta de suas explicações demasiado simplistas e inadequadas do processo de compreensão e interpretação (ambas remeteriam o neo-formalismo a uma visão detetivesca da interpretação, através da qual a função do intérprete seria tanto de compreender a mensagem transmitida por um emissor quanto decodificar uma mensagem previamente codificada), o modelo inferencial ao qual Bordwell se encontra comprometido é também contraditório e uma explicação inadequada da compreensão e interpretação. Talvez a resposta resida em entender que compreensão e interpretação não se conformam rigidamente a qualquer um desses modelos e, além disso, que os modelos não são mutuamente exclusivos. Espectadores fazem uso de schematas enquanto compreendem e interpretam filmes; mas eles também se digladiam com as mensagens de um texto, assim como suas respostas aos textos narrativos os envolvem na atividade de decodificar mensagens que haviam sido previamente codificadas. Nem o

\footnotetext{
${ }^{16}$ Gaut extrai três diferentes noções de construção dos argumentos de Bordwell e as examina para ver se alguma delas prova que "os sentidos são construídos, não encontrados". A primeira, "construção conceitual”, na qual os conceitos são mapeados em hipóteses usando o conhecimento de fundo condizente com a teoria construtivista da percepção, não é base para se pensar que os temas da percepção e do sentido são constructos. O segundo, "construção normativa", segundo a qual os espectadores são dirigidos a imaginarem o que veem, também não prova que os espectadores, por conta disso, determinam o que devem imaginar. E, finalmente, a versão mais sólida do construtivismo, da escola crítica construtivista - inerente nas reinvindicações de Bordwell sobre a natureza da interpretação como uma atividade na qual o mapeamento crítico dos campos semânticos em relação aos filmes fazendo uso de schemata, heurística, suposições e hipóteses, todos derivando sua validade e eficiência das instituições críticas - é uma teoria falsa da interpretação. Isso porque Gaut demonstra que o que deveriam provocar apelo à interpretação não são as normas das instituições críticas, mas as que governam o filme em seu contexto histórico. Portanto, o neo-formalismo tem falhado em provar que a construção genuína reside no coração da compreensão e interpretação dos filmes. Gaut também recomenda que a "poética histórica" de Bordwell e Thompson deveria se libertar do peso do construtivismo de forma mais ampla, que é atualmente incompatível com a renovada atenção ao contexto histórico que reivindicam. Entretanto, como esse capítulo tem argumentado o conceito de contexto histórico dos autores necessita ser ampliado em seu escopo.
} 
modelo comunicacional nem o modelo da significação precisam se adequar integralmente as explicações intencionalistas, pela localização desses modelos e as mensagens que comunicam nos contextos da cultura e da história, poderíamos observar no ato individual de sentido, os ritmos da vida, os valores, as estruturas de crenças de seu contexto. Reconciliando os processos dos modelos que Bordwell opõe, e utilizando o sentido de significação bakhtiniano e barthesiano, teríamos uma "hermenêutica" e uma "poética da interpretação"17 que seria livre das contradições que encontramos na elaboração de Bordwell.".

De fato, as contradições na resposta de Bordwell à interpretação persistem por conta dele insistir na divisão entre compreensão e interpretação, sendo a última observada como a atribuição de sentidos implícitos e sintomáticos a um texto. Existem duas cisões aqui que são importantes e que precisam ser abordadas. A primeira tem a ver com o cisma entre os diferentes tipos de sentido em um texto, que são o referencial e o explícito, sendo conectados com o syuzhet e a fábula de um filme, e são o domínio da compreensão, sendo observados como distintos do sentido implícito e sintomático do texto. George Wilson demonstrou que é impossível observar os sentidos implícitos da narrativa de uma obra cinematográfica como separados de seus referenciais já que os "sentidos implícitos de um filme são inseparáveis de uma teia de relações que constitui a fábula retratada no filme" (Wilson, 1997: 226). De forma semelhante, os sentidos sintomáticos de um texto, que Bordwell identifica com sua ideologia reprimida, não podem ser vistos como sentidos a priori que os críticos sobrepõem aos filmes, já que as questões ideológicas são inerentes nas escolhas construtivas que os realizadores fazem - escolhas que se relacionam ao gênero, forma, estilo e caracterização tanto quanto se encontram relacionadas a qualquer sentido reprimido que a narrativa revela, a despeito do diretor, através de "suas lacunas e

\footnotetext{
${ }^{17}$ Bordwell opõe esses dois e considera que oferece "não uma hermenêutica - um esquema para produzir interpretações válidas ou valiosas - mas uma poética da interpretação” (1989b: 273). É espantoso que a distinção entre as duas seja tão óbvia quanto é para Bordwell. De fato, Aristóteles, de quem Bordwell certamente buscaria uma filiação crítica, parece ter feito ambas em sua "Poética".
} 
fissuras". ${ }^{18}$ Bordwell apontou apropriadamente para a obra dos críticos do Cahiers e de Screen por conta desse senso de determinação ideológica. A obra de Thomas Schatz sobre os gêneros também enfatiza as relações inextricáveis entre gêneros e ideologias (ver Schatz, 1981: caps. 1 e 2).

Como uma historiadora de gêneros, formas e estilos, a poética neoformalista inicia, Bordwell assegura, as suposições concretas inerentes ao ofício de realizador (1989b: 269). Mas gêneros, formas e estilos envolvem muito mais que a capacidade do realizador. Como Bakhtin aponta, os gêneros "acumulam formas de ver e interpretar aspectos particulares do mundo." (1986b: 5) Os gêneros codificam respostas culturais, são similarmente codificados e carregam com eles o peso da significação da história e da cultura. Um estudo de gênero deveria confrontar as questões implícitas e ideológicas que os gêneros carregam dentro de si. Portanto, qualquer compreensão de características de gênero, formais e estilísticas em si mesmas, puramente ao nível da habilidade, separa a "forma" de sua particularidade histórica, "conteúdo" cultural e contexto da narrativa. Ainda que Bordwell seja ostensivamente contra a cisão forma-conteúdo, separando os sentidos referenciais e explícitos dos implícitos e sintomáticos e privilegiando a análise de formas estruturais sobre a "temática", ele está, na realidade, fazendo justamente isso. Qualquer poética histórica de um gênero, de uma forma ou de um estilo que não analise as questões implícitas e sintomáticas de um texto - em outras palavras, que não analise o texto holisticamente - seria tão inadequada quanto uma história da arte narrativa seria enquanto interpretação.

Isso nos leva a uma segunda ruptura que resulta da separação entre compreensão e interpretação por Bordwell. Observando a interpretação como uma atribuição de sentidos implícitos e/ou sintomáticos a um texto, e com a

\footnotetext{
${ }^{18}$ Essa compreensão sintomática de sentido ganhou moeda corrente no editorial de Jean-Louis Comolli e Jean Narboni, "Cinema/Ideologia/Crítica", na Cahiers du Cinema. Posteriormente formou-se o ímpeto por muita interpretação crítica nos anos 70, particularmente na Cahiers e em Screen. O capítulo 4 de Bordwell em Making meaning, "Interpretação sintomática", é um relato bastante claro e útil da história das ideias críticas e dos movimentos na teoria e crítica de cinema.
} 
compreensão de que esses sentidos vêm de esquemas de instituições críticas que a crítica então mapeia quase randomicamente em hipóteses nos filmes, Bordwell implicitamente separa a atividade interpretativa, e também o texto, do universo cultural do qual faz parte. Isso também é claro de sua caracterização da atividade interpretativa. De acordo com Bordwell, "o conhecimento do texto não é o efeito mais saliente da atividade interpretativa", que não tem como objetivo proporcionar explicações "causais" ou "funcionais" (1989b: 257). Não é o texto, mas "nosso processo perceptivo, cognitivo e afetivo" que são os temas de nossa interpretação. Ao caracterizar a atividade de interpretação nesses termos, Bordwell proporciona uma desconexão entre o texto e "nossos processos perceptivos, cognitivos e afetivos" que são "efeitos" do texto (p. 257), desse modo nos bloqueando completamente do mundo exterior ao texto, sem meios para acessá-lo. A experiência comum de compreender e interpretar textos se dá de outro modo. Dentro da definição de interpretação de Bordwell, o texto funcionaria meramente como catalizador ou pronto a encorajar "uma disciplinada especulação sobre as possibilidades de sentido" (p. 258). O texto, portanto, perde sua especificidade ${ }^{19}$ e seu valor como uma representação de um mundo que, quando respondemos a ele, eleva nossa "compreensão" no sentido de "conhecimento"; ${ }^{20}$ conhecimento de um mundo similar ao nosso ou talvez ainda um pouco diferente, assim como de nós mesmos e de nossas respostas emocionais, mentais e intelectuais. Embora Bordwell esteja mais que correto em observar que a interpretação "responde a um crescente sentido de interesse em

\footnotetext{
${ }^{19} \mathrm{O}$ argumento contrário a Bordwell aqui é semelhante ao que Malcolm Turvey formulou sobre a teoria da resposta emocional do espectador aos filmes de ficção de Murray Smith e Noel Carroll em TURVEY (1997). Turvey argumenta que ao identificar uma entidade mental - i.e., imaginação ou pensamento como o "agente causal da emoção do espectador durante sua assistência aos filmes de ficção", Smith e Carroll divorciam a resposta emocional do espectador da "particularidade sensível do meio cinemático", posição contraposta por "descrições da linguagem ordinária da experiência dos filmes de ficção", e que Smith e Carroll encontram dificuldades tanto para provar quanto para ignorar. Ver pp. 432-8 para esse argumento.

${ }^{20}$ Ver nota 8.
} 
motivos, intenção e responsabilidade ética demonstrando que obras de arte não oferecem guias explícitos para que o comportamento possa fazer surgir questões significativas de pensamento, sentimento e ação." (1989b: 258), ele não percebe que a interpretação somente é capaz de fazê-lo explicando e interpretando as situações e teias de relações que um texto representa. Se, de fato, a interpretação "reativa e revisa nossas molduras comuns de compreensão" (p. 257) ${ }^{21}$, somente o faz porque o que está sendo interpretado é o texto, e interpretação é sobre a compreensão do universo do texto, da cultura que o produziu e, por extensão, das sociedades humanas e processos de vida. Nem o texto nem "nossos processos perceptivos, cognitivos e afetivos" existem num vácuo, e é somente quando reconhecemos a natureza contextual da vida, e também da especulação, que o ato interpretativo pode ser corretamente valorizado.

E é porque Bordwell avalia "a maior façanha da interpretação" como "sua habilidade de encorajar reflexões sobre nossos esquemas conceituais"22 que ele de fato subvaloriza os benefícios reais e conquistas da interpretação. Tendo criado um abismo entre interpretação e crítica histórica, e com seu forte viés contra a primeira, ele não possui opção a não ser redutivo ou apropriado quando responde que as intepretações não podem ser desconsideradas como instáveis, improvisadas ou completamente "finalistas" (i.e., baseadas em codificações a priori do que um filme, em última instância, significa ${ }^{23}$ ). Comentando da contribuição positiva que a crítica dominada pela interpretação efetuou para a criação de uma tradição para os estudos sobre cinema, Bordwell afirma:

A concepção do texto como revelando sintomaticamente tensões culturais introduziu uma poderosa moldura de referência. Reivindicar unidade com relação à produção

\footnotetext{
${ }^{21}$ Bordwell observa "a maior façanha da interpretação" como "sua habilidade a encorajar (...) reflexões sobre nossos esquemas conceituais. Por domesticar o novo e aprofundar o conhecido, a instituição interpretativa reativa e revisa nossas molduras comuns de compreensão".

22 Ver nota 21.

${ }^{23}$ Bordwell empresta o termo e a ideia de Tzvetan Todorov, que afirma que "é o conhecimento prévio do sentido a ser descoberto que guia a interpetação." (1982: 254, citado por Bordwell, 1989b: 260)
} 
de um auteur, postular que o cinema possui três olhares, e sugerir que um gênero pode constituir uma intersecção de natureza e cultura organizou uma grande quantidade de informações dentro de uma nova perspectiva. (1989b: 256)

Os benefícios da interpretação caracterizados por Bordwell, aqui, parecem bastante ineficazes, mesmo insignificantes. Interpretações efetivas acrescentam somente "poderosa[s] moldura(s) de referência" ou organizam "informações dentro de uma nova perspectiva"? A intepretação não acrescenta nada à nossa compreensão do valor, ao perpétuo valor e funções da arte narrativa na sociedade? É típico de Bordwell não comentar as percepções em relação à vida humana, processos sociais, a natureza intrincada da interação social e humana, e a determinação histórico-cultural da ação humana que ganha com uma crítica que tenha como centralidade a interpretação. Embora não se queira transformar a crítica de Bordwell às interpretações inadequadas, seria desvalorizar a força e função da interpretação observar seus exemplos positivos como meramente "inovadoras molduras de referência" que têm "aumentado nossa compreensão do que pode ser percebido e apreciado nas obras de arte" (p. 256). Ao tornar positiva uma atividade interpretativa como aquela que permite campos semânticos inovadores apanhar sugestões até então despercebidas no texto, se empobrece a análise estilístico e formal, assim como temática.

Ao mesmo tempo, quando Bordwell dá exemplos de atividade interpretativa que também vão de encontro a sua demanda por uma "crítica sensível" (p. 264) e uma análise dos elementos formais, ele se apropria da obra como uma forma de "poética histórica" e considera que "a construção dos sentidos implícitos e sintomáticos pode coexistir com a análise da forma e do estilo em dadas circunstâncias históricas" (p. 267). Os escritos de Bazin e Burch são exemplos ${ }^{24}$.

\footnotetext{
${ }^{24}$ Ao longo de Making meaning e na "Poética histórica do cinema", Bordwell observa a obra de Bazin como um exemplo dos mais elevados padrões da crítica histórica e um modelo exemplar de "poética cinemática". Ele admite que Bazin também formula uma crítica interpretativa. Ainda que afirme que a obra de Bazin, assim como a de Burch e dos realizadores soviéticos, demonstra que a "construção de sentidos sintomáticos e implícitos pode coexistir com a análise da forma e estilo em dadas
} 
A questão não é que Bordwell se encontre equivocado nessa consideração, mas antes que as duas atividades - a crítica sensível que recobre a "criticidade da arte" (P. 264) e a construção de sentidos implícitos e sintomáticos, com a suposição que a composição e efeitos de um filme são veículos da primeira - são mutuamente exclusivos e contraditórios. A formulação de Bordwell de uma diferença e divisão entre interpretação e crítica histórica demanda essa polaridade. De outro modo, uma análise da forma e estilo histórica e culturalmente nuançada que as observa como portadoras de sentidos sintomáticos explícitos, assim como implícitos, pode ser vista como a forma de interpretação mais compreensiva. Da mesma maneira que uma análise histórica e cultural da forma e estilo não necessita ser oposta a uma crítica histórica, igualmente uma ênfase na criticidade da arte pode complementar e aumentar a compreensão interpretativa de um texto e seu universo.

A despeito de sua hostilidade e objeções à interpretação, Bordwell declara, em vários momentos, que proibir todas as convenções da interpretação seria empobrecer os estudos de cinema. Ainda aqui permanece a acusação de que os intérpretes têm prestado escassa atenção à forma e estilo dos filmes. Ele parece se opor ao que denomina modelo circular-concêntrico, por meio do qual aspectos do cenário ou trabalho de câmera amplificam ou comentam a respeito da interação entre os personagens. Isso poderia subordinar o estilo do filme a questões consideradas importantes em outras disciplinas (p. 260-1). Ainda que Bordwell esteja mais do que correto em nos alertar que leituras doutrinárias de filmes podem observar quaisquer aspectos de seus conteúdos e estilos em termos de uma narrativa maior, e seus muitos exemplos podem apontar corretamente às frequentes formulações absurdas que resultam de uma abordagem que aplica sentidos pré-determinados para ler imagens visuais ou estilos cinematográficos (por exemplo, observar os espelhos como significando reflexividade), seria igualmente desastroso e unilateral se concentrar somente nos 
"princípios de acordo com os quais os filmes são construídos e através dos quais atingem efeitos particulares" (1989a: 371), particularmente quando estes princípios não se encontram localizados no mais amplo ambiente ideológico sócio-cultural de sua época.

Outra questão igualmente importante para a poética histórica é como e por que motivo tais princípios surgiram e se modificaram em particulares circunstâncias históricas. Essa análise histórica dos princípios de transformações da construção fílmica é louvável. Entretanto, é importante compreender que a consideração dos princípios elaboradores do "por que" se tornam mais consistentes quando nos levam face a face com questões da economia, ideologia, ética, moralidade e valores da sociedade na qual os filmes são produzidos ${ }^{25}$, com questões de como e por que gêneros sustentam formações ideológicas e psicológicas e são vinculados a determinantes mais profundos da psique cultural - de fato, todas as questões que são centrais aos sentidos implícitos e sintomáticos dos filmes, considerado o domínio da interpretação. E qualquer estudo de princípios elaborativos que não confronte essas questões ficaria aquém das verdadeiras medidas que o próprio Bordwell formula para sua "poética histórica". Na mesma linha de raciocínio, a identidade do neo-formalismo enquanto poética histórica, com sua ênfase "nas normas, dispositivos, sistemas e funções historicamente cambiantes" que "requer que 0 analista complemente o escrutínio de filmes individuais com o estudo de um espectro amplo de filmes (1989a: 382), seria incompleta sem o estudo da história, sociedade e cultura que dá forma a esse

\footnotetext{
${ }^{25} \mathrm{Em}$ sua "Poética histórica do cinema", Bordwell afirma que "nada impede o seu formulador de discutir que a economia, a ideologia, a luta de classes ou disposições inerentemente sociais ou psicológicas operem como causas de dispositivos ou efeitos elaboradores" (p. 374). Trata-se de uma concepção bastante semelhante à concepção formalista de "material" que Bakhtin critica: "Os formalistas chamaram a motivação de dispositivo, 'material', e consideraram todo significante ideológico igualmente como 'material'”. Porém, como Bakhtin apontou, "a redução do material a mera motivação condena o dispositivo ao completo vazio" e, portanto, "a divisão da construção poética em dispositivo e material é claramente indefensável” (Bakthin e Medvedev, 1978: 112, 116).
} 
conteúdo. ${ }^{26} \mathrm{~A}$ própria forma carrega um sentido sintomático e, portanto, uma hostilidade ao último significa uma leitura incompleta da forma. A sugestão de Bakhtin é que a "poética acadêmica deveria se adequar a um conjunto de séries de desenvolvimento literário geradas" (Bakhtin e Medvedev, 1978: 159), sendo um importante corretivo ao senso de história cinemático de Bordwell, que lida somente com séries fílmicas em interação com as leis de desenvolvimento socioeconômicos sem qualquer contextualização de "outras séries ideológicas."27

O que se encontra em discussão aqui é que questões ideológicas que Bordwell bane para o reino da "interpretação sintomática" são centrais para qualquer compreensão da forma ou "opções de elaboração" abertas a várias "conjunturas históricas" (1989a: 381). Qualquer compreensão das últimas deve aceitar uma visão da história do cinema que não é linear, teleológica, que se move do cinema clássico passando pelo cinema de montagem soviético e depois o cinema de arte, e daí por diante. ${ }^{28} \mathrm{~A}$ compreensão de Bordwell que o cinema de Hollywood, o

\footnotetext{
${ }^{26}$ Estudar "um amplo espectro de filmes" sem estudar o contexto desses filmes seria observar o cinema somente em termos de séries fílmicas com nenhuma compreensão da relação dessas séries com "outras séries ideológicas". Essa também é uma crítica presente em Bakhtin aos formalistas que, de acordo com ele, consideram "as séries de história literária, as séries de obras artísticas e seus elementos construtivos de forma completamente independente de outras séries ideológicas e de desenvolvimento socioeconômico" (Bakhtin e Medvedev, 1978: 159). Ainda que Bordwell leve em conta o desenvolvimento socioeconômico, não considera adequadamente suficiente a importância de outras esferas ideológicas para a história do cinema.

${ }^{27}$ Ver nota 26.

${ }^{28}$ Bordwell considera que não é necessário "assumir qualquer modelo de causa e mudança" quando envolvido no empreendimento da poética histórica. Ele aponta que Bazin, na "Evolução da linguagem cinematográfica" (1990) dá uma explicação teleológica do desenvolvimento da forma cinematográfica (1989a: 374). Bordwell aponta para outros modelos de causa que o teleológico, baziniano. O "intencionalista", que se "centra em atos mais localizados de escolha e de negação". Em oposição a isso, seu próprio modelo é um "funcionalista", "através do qual uma dinâmica institucional de filmagem sofre restrições e prefere opções que se adequam as normas sistêmicas como um todo" (p. 374). Embora seu uso do modelo funcionalista possa ser verdadeiro para sua discussão do cinema hollywoodiano em The classical Hollywood cinema (Bordwell et al, 1985), sua discussão sobre diferentes tipos de cinema quando enfatiza a historicidade das diferentes "opções elaborativas"
} 
cinema de montagem soviético, o cinema de arte e outros tipos de cinema fazem uso de formas de elaboração (1989a: 381) deveria igualmente admitir que, juntamente com o posicionamento histórico, questões ideológicas são importantes para as escolhas que esses diferentes tipos de artista efetuaram. Portanto, sua sugestão por uma "crítica sensível" à forma e ao estilo que leve em conta a "palpabilidade do objeto" (Viktor Schlovski, citado in Bordwell, 1989b: 264), e uma análise histórica de filmes particulares, com especial atenção aos processos que os levaram a serem o que são, deve aceitar que a forma somente pode ser plenamente compreendida quando todos os sentidos que ela carrega explícitos e referenciais, implícitos e sintomáticos - são permitidos em sua elaboração. O próprio exemplo da leitura crítica e histórica de Vance Kepley da obra de Dovjenko por Bordwell demonstra que a forma carrega sentidos ideológicos e sintomáticos. ${ }^{29}$ Portanto, o divórcio de se estudar a forma do sentido que ele carrega é um impulso extremamente deslocado, e que poderia contrariar o projeto da poética histórica. A interpretação e a poética histórica podem não ser inimigas, como Bordwell tem assumido em sua explanação sobre a construção de sentido.

Observar o sentido como relacionado aos "efeitos" de uma obra (p. 270) é tão equivocado quanto separar o sentido da forma. A forma e o sentido do texto geram efeitos. Da mesma forma, seria inadequado lidar com temas meramente

disponíveis aos realizadores em "várias conjunturas históricas" implica um modelo teleológico de história do cinema (1989a: 381).

${ }^{29}$ Bordwell compreende que Vance Kepley "demonstrou que os elementos mitográficos misteriosos dos filmes possuem referências concretas extra-textuais, e que as mensagens explícitas dos filmes são traços de diversos propósitos políticos, algumas vezes conflitantes. Kepley pode continuar descrevendo projetos ideológicos e propondo leituras sintomáticas instruídas na base de alguma evidência histórica específica que Macherey e os críticos do Cahiers nunca foram capazes de reunir." Porém, ele observa isso sendo um exemplo de como, ao nos voltarmos "para a história", "descobrimos que os filmes funcionam de modo que ainda não conhecíamos", sem admitir que a interpretação sintomática pode de fato ajudar a compreender como os filmes funcionam em diferentes contextos históricos (1989b: 265-6). 
como "princípios construtivos" ou "efeitos de princípios construtivos", como Bordwell propõe (1989a: 375), pois os temas incorporam os sentidos de uma obra, sentidos que estruturam o significado do contexto cultural de um texto. Enquanto Bordwell observa sentido, estrutura e processo - os três aspectos de qualquer sistema representacional - como centrais à poética histórica (p. 576), não percebe a contradição de considerar que as temáticas somente são importantes se forem vistas como princípios de elaboração. Os temas contêm o sentido de uma obra, mas eles são estruturados e dão forma, portanto a significação somente surge através dos princípios de elaboração de um filme. Como Bakhtin diria, "não existe conteúdo sem forma e forma sem conteúdo" (Bakhtin e Medvedev, 1978: 140). Lidar com temas como se existissem fora da forma e estrutura de um texto (que Bordwell critica) é tão deslocado quanto o que ele próprio sugere. Observar os temas como princípios construtivos ou seus efeitos seria ler o sentido do filme puramente em termos "estilísticos/perceptivos/lógicos" (Carney, 1989: 45) e princípios afetivos - portanto, ler a narrativa somente como algo essencialmente a respeito das formas de expressão e suas implicações afetivas. O que é deixado de fora é um espectro inteiro de situações, conflitos e escolhas com seus concomitantes pensamentos, sentimentos e ideias que apresentam $o$ leitor/espectador com possibilidades hipotéticas para entreter e seguir, que podem constituir o apelo perene da narrativa - possibilidades que podem não se encontrar presentes em nossas vidas, mas oferecer explanações de nosso mundo e da condição humana e nos possibilitar lidar com nossas próprias situações de forma muito mais apropriada.

Os efeitos de uma obra são múltiplos e podem variar do simples "prazer", do qual Bordwell se encontra consciente, ${ }^{30}$ à especulação sobre os potenciais e possibilidades abertas aos indivíduos ou meditações sobre a condição humana. Bordwell se encontra completamente correto em considerar que os princípios de

\footnotetext{
${ }^{30}$ Entretanto, Bordwell é cético sobre o prazer da interpretação de um filme: "em 1975 Laura Mulvey escreveu que sua teoria solicitava extirpar o prazer ao se assistir um filme. Talvez seja agora tempo de algo mais controverso: se extrair o prazer da interpretação de um filme”. (1989b: 262-3).
} 
elaboração e os efeitos que possuem são resultados de escolhas cuidadosamente deliberadas por seus realizadores (1989b: 268-9). Entretanto, os efeitos particulares que uma obra possui não são somente o resultado dos sentidos estruturados por seus temas, mas também escolhas deliberadamente ideológicas que os realizadores fizeram. ${ }^{31}$ Se a poética envolve, juntamente com a análise da construção de um texto, um estudo de seus efeitos, como Bordwell assegura (1989b: 270; 1989a: 383), então o estudo da recepção de um texto deveria envolver não somente a compreensão da ideologia do texto, mas também a suposição de sua efetividade proveniente de um reconhecimento que as ideologias, os sentidos e as mensagens de um texto terão uma recepção que é simpática. Leitores/espectadores, de fato, pertencem a "comunidades de leitura" ou "formações de leitura", e um texto possui seu efeito precisamente porque os leitores interpretam os textos como os compreendem, e, portanto, o crítico possui a garantia retórica de sua "iniciativa iluminadora", a cujo respeito Bordwell é cético (1989b: 255). ${ }^{32}$ É irônico que, ao formular a diferença entre a atividade do leitor/espectador e a do crítico, Bordwell vá contra uma das pressuposições fundamentais de qualquer estudo sobre os "efeitos" de um texto: que o texto produz efeitos somente se o público reconhece seus significados. Do mesmo modo, um crítico somente interpreta um texto se reconhece as respostas emocionais e suposições que os elementos do texto são destinados a evocar. $E$ ele somente pode fazê-lo se participa do ritual, ainda que de forma distanciada. Portanto, se a poética histórica for tanto sobre os efeitos quanto sobre os princípios da forma construtiva, deve levar em conta todos os sentidos que

\footnotetext{
${ }^{31}$ Um típico filme de gênero, por exemplo, perpetua certas ideologias que não se encontram codificadas a esses gêneros, mas que são utilizadas de forma bastante consciente pelos realizadores: ver a obra de Thomas Schatz sobre gêneros, particularmente Hollywood Genres (1981). [No Brasil, O gênio do sistema. São Paulo: Cia. das Letras, 1987]

${ }^{32}$ Bordwell é crítico à tendência dos críticos de projetarem suas atividades interpretativas de "volta a espectadores 'comuns' ou [...] 'ingênuos' que pertencem às 'comunidades de leitura' ou são constituídos por 'formações de leitura", já que, definindo o que quer que os espectadores façam como interpretação, o crítico assegura a garantia retórica por sua iniciativa mais perspicaz."
} 
Bordwell observa como do domínio da interpretação - os sentidos implícitos sintomáticos altamente suspeitos que possuem implicações simbólicas e ideológicas.

III

Bordwell afirma, ao final de Making meaning, que sua intenção não é de "repudiar a interpretação, mas de situar seus protocolos dentro de uma investigação histórica mais ampla" (1989b: 266). Ele acredita que a poética neoformalista, "embora se concentrando no contexto histórico, forma narrativa e estilo cinematográfico, não exclui a interpretação temática, mas absorve num sistema dinâmico" (1989a: 385). Entretanto, tão profunda é sua suspeita dos sentidos sintomáticos e implícitos, e tão comprometido ele é com uma exposição da forma e do estilo e de sua localização histórica sem necessariamente relacioná-lo aos seus significados temáticos, que suas próprias leituras dos textos cinemáticos frequentemente resultam na apresentação do "filme como intrigante ou desafiador, talvez porque suas operações residam aquém ou além da interpretação" (1989b: 271). ${ }^{33}$

Utilizarei como exemplo sua leitura de Ordet, de Carl Dreyer, para demonstrar que embora Bordwell apresente o filme como intrigante e desafiador através da análise de seu estilo, sua leitura é inadequada e empobrecedora porque se recusa a ir de encontro aos seus temas ou a observar a encarnação do conteúdo na forma.

A fortuna crítica sobre Dreyer é polarizada entre "tradicional-temática" e a "perceptiva-formalista" (Carney, 1989: 22). Ao contrário dos críticos temáticos, David Bordwell é extremamente consciente da importância do estilo. Posicionando-se à distância dos três principais tipos de resposta crítica antes dele - a religiosa, a humanista e a estética - Bordwell mantém que sua posição formalista o proporciona a responder adequadamente a questão do estilo e,

\footnotetext{
${ }^{33}$ Porém, como argumentei nesse texto, são essas duas atividades - a de interpretar e a de uma "poética" - inerentemente opostas como Bordwell as torna?
} 
portanto, ele lê a obra de Dreyer como essencialmente sobre "problemas de ordem" e "problemas de interpretação" (1981: 1-3). Porém, como Raymond Carney aponta, a leitura de Bordwell reduz os filmes de Dreyer a um "conjunto de trocas estilísticas/perceptivas/lógicas" e desconsidera completamente as dimensões emotivas e psicológicas da experiência. Sua leitura do estilo de Dreyer como funcionando independentemente de sua narrativa é problemática; ao localizar o valor de sua obra em desconstruir tanto a "realidade perceptiva ordinária" e as formas expressivas de "outras obras artísticas", Bordwell posiciona a única função criativa do estilo como essencialmente negativa - desconstruir, parodiar ou brincar com formas de representação que, como Carney aponta, é "uma absoluta trivialização das possibilidades de expressão artística" (1989: 45-8). Bordwell, portanto, observa a narrativa como essencialmente sobre os significados da expressão e suas implicações afetivas.

As limitações da abordagem de Bordwell a Ordet se tornam óbvias, já que ele perde completamente o significado contemporâneo das preocupações de Dreyer com relação à forma anacrônica de paixão medieval dentro da qual Dreyer incorpora sua narrativa. Então, para Bordwell, "tão grande foi a ligação de Dreyer à a-historicidade" que seus filmes não podem ser vistos como "refletindo posições ideológicas contemporâneas". Mesmo a religião, que normalmente seria associada com a ideologia, Bordwell observa como tendo peso ideológico somente enquanto forma de "situar a ação numa moldura de referencia a-social e atemporal [...] validando-a como representação e teorizando a verdadeira produção de narrativa do filme" (1981: 192-3). Ao contrário de ler as questões religiosas como temas que requerem interpretações, Bordwell os transforma em elementos formais de nenhuma reverberação temática ou significado. Ao fazê-lo, perde o significado do filme e empobrece suas inquietações. Ele observa, em Ordet, a "unidade narrativa típica de Dreyer", encontrando "sua mais consumada justificação - a religião" - e o "Cristianismo se torna o mais avassalador artificio formal de Dreyer" (146-7). A leitura formalista de Bordwell sobre o Cristianismo em Ordet é problemática, precisamente por conta de ser uma leitura dos códigos hermenêuticos e pro-airéticos da narrativa, sem perceber que os significados 
desses códigos não podem ser compreendidom fora do contexto dos códigos sêmicos, referenciais e simbólicos. ${ }^{34} \mathrm{O}$ Cristianismo não é apenas um artifício formal em Ordet, mas, antes, a própria tessitura e textura da vida social e cultural que Dreyer deseja explorar, assim como o que se encontra ameaçado de extinção na descrença difusa e destrutiva do momento contemporâneo. Ao recontar uma história antiga em um contexto moderno, ao fazer uso de uma forma antiga (a da paixão-mistério) para estruturar o sentido de uma experiência moderna, ele não somente demonstra a continuidade geral da experiência cultural, mas também expressa um desejo coletivo de redenção do desespero da dúvida na qual a modernidade mergulhou a cultura ocidental. As "profundamente poderosas correntes da cultura" (Bakhtin 1986b: 3) são, de fato, demonstrações palpáveis, se formos sensíveis o suficiente e tomarmos as sugestões de Bakhtin e Barthes de ler a narrativa como um significado cultural.

A inabilidade de Bordwell de vincular questões temáticas e formais é óbvia, já que ele converte mesmo interesses temáticos como a análise da religião em estratégias formais e, portanto, perde o significado contemporâneo do uso que Dreyer faz de formas e objetos de épocas passadas. Ele observa a centralidade dos objetos de arte na obra de Dreyer "como sintomáticos da tendência de Dreyer de imprimir o social no que circunda os personagens, mas, ao mesmo tempo, remover o social através de objetos decorativos selecionados pelos personagens" (1981: 195). Fica claro que Bordwell não compreendeu o processo de simplificação operante no filme de Dreyer. Os retratos de figuras patriarcais nas paredes das duas casas no filme sugerem sutilmente as forças que controlam as formas de interação social nesse universo. Curiosamente, as cenas do encontro e da discussão entre Morten e Peter são compostas como pinturas de Rembrandt, assim como, anteriormente, Inger é frequentemente filmada em composições semelhantes a Vermeer, que transformam a simplicidade de um gesto rotineiro em arte transcendental. A intertextualidade não é casual para, como Raymond

\footnotetext{
${ }^{34}$ Ver a discussão na p. 7.
} 
Williams apontou, abrir o filme para um contexto mais amplo, traçando relações entre os diferentes sistemas significantes de uma cultura (Williams, 1982: 12-13; citado por Gunning, 1991:11).

E é irônico que Bordwell, tão comprometido em compreender a forma e o estilo em um contexto histórico, perca o significado histórico e contemporâneo da forma em Dreyer. Isso se dá precisamente porque ele não se engaja de forma criativa com as questões temáticas da obra de Dreyer, sendo que sua leitura da forma não é impregnada com a visão da obra. Uma breve discussão de uma cena crucial no filme tornará isso mais claro. Enquanto Inger luta por sua vida no trabalho, sua filha Maren e seu cunhado supostamente louco Johannes conversam rapidamente no salão. Essa cena entre Johannes e a pequena Maren encontra-se em contraste direto com cena na qual ela chega para o avô, prevendo a morte de sua esposa. Enquanto ele a distrai e a leva para a cama, sem responder qualquer de suas questões ou mesmo leva-las a sério, Johannes e a menina se tomam a sério, e Maren o convence do poder tanto do amor quanto da fé humana, uma fé que torna possível a ressureição dos mortos. Ocupando a centralidade da composição pela primeira vez no filme por um movimento simultâneo de panorâmica e arco da câmera, Johannes é mais uma vez codificado semicamente como o Salvador. ${ }^{35}$ Quando o movimento cessa, com Johannes e Maren compostos centralmente em primeiro plano, com a porta do quarto de Inger ao fundo, as conexões vitais entre

\footnotetext{
${ }^{35}$ Ao longo do filme, Johannes é apresentado em termos icônicos que são semicamente evocativos da figura de Cristo, embora também exista alguma ambivalência nessa apresentação. Algo que fica claro na primeira cena, quando Johannes sai em direção ao pântano e se dirige a uma plateia imaginária, condenando-os por sua ausência de fé no Cristo renascido. Ainda que a cena seja semicamente evocativa do Sermão na Montanha de Cristo, existe igualmente um profundo contraste entre as duas figuras, através da cisão produzida pelas diferenças de seus respectivos sermões, a saber, que Johannes condena a congregação imaginada por sua ausência de fé nele enquanto Cristo revivido, enquanto o sermão de Jesus a seus discípulos e outros contém as Beatitudes e outros importantes fundamentos do ensinamento Cristão (Ver Mateus, 5-7; Lucas, 6: 20-49). Apesar da ambivalência da primeira cena, Dreyer indica a ilusão de Johannes mas, ao mesmo tempo, sugere a possibilidade de visão e o potencial de ser um salvador através da imagem-sema utilizada para apresentá-lo.
} 
esses três indivíduos e as forças que representam se tornam claras. Se existe uma fé verdadeira, é nesse triunvirato, com a chegada da fé infantil, infinita crença no Divino, ternura, compaixão, compreensão e um vasto e terno amor. A despeito da aparente indiferença e distração de Johannes, ele possui qualidades que pertencem a esta fé alternativa e é, de fato, um membro central, algo que somente Inger e Maren realizam implicitamente. Bordwell analisa a façanha técnica dessa sequência. Ele descreve o movimento da câmera, tais como estes arcos se movendo em uma direção, enquanto a panorâmica vai no sentido oposto. $O$ efeito resultante é o de manter uma equidistância das figuras que emergem de forma escultural enquanto o espaço se torna dinâmico (1981: 156-8). No entanto, ele falha na observação do significado narrativo desse movimento como descrito acima.

Uma análise adequada ou descrição de forma e estilo deve confrontar seu significado temático e filosófico. O estilo do filme, que Dreyer acreditava comunicar a verdade da visão do artista ou a interpretação pessoal de sua realidade (Dreyer, 1973), ${ }^{36}$ não opera de forma alguma em desacordo com os interesses narrativos desse filme, pois ambos se encontram engajados na tarefa de significar uma realidade e, portanto, um contexto e uma cultura. $\mathrm{O}$ universal não é uma essência flutuante que precisa ser captada na teia de uma visão artística ou realizada através de uma meditação ou verdades vagamente eternas. Antes, ele é realizado através de especificidades concretas de uma cultura e uma realidade que é enraizada no tempo e no espaço. E é a tal realidade que Dreyer se dirige em todos os seus filmes, a despeito da abstração de sua técnica e da aparente atemporalidade de seu tema. Ordet é proveniente de um profundo confronto com as implicações da modernidade e sua crise de fé, e o sentido dessa crise que o filme explora, proporcionando ao mesmo tempo uma visão utópica da fé que, na sua afirmação da Vida, presenteia uma lição sobre o valor daquela que transcende as forças racionalistas da modernidade. Como outros

\footnotetext{
36 "O estilo [...] é a forma do artista dar a sua expressão do material[ ...]. Através do estilo, ele leva os outros a ver o material através de seus olhos" (Dreyer, 1973: 127).
} 
modernistas, Dreyer retira da história a busca por formas que transmitem o alcance dos sentidos que seus temas demandam. Ao fazê-lo, o que ele de fato consegue é demonstrar as continuidades da cultura, que persiste a despeito da ruptura da modernidade. Se "formas de pensamento" (Bakhtin, 1986b: 5) persistem sobre o tempo numa cultura, então as intuições genéricas podem ser mobilizadas a estabelecer uma relação criativa e plena de sentido com a tradição no contexto da força divisionista da modernidade, ainda quando o passado, com suas estruturas sociais retrógadas, seja criticado, e o presente busque por uma autêntica forma de relacionamento humano. Em ambos os casos, é com "o mapa dos sentidos numa cultura" (Hall, 1972: 65, citado por Lesage, 1985: 481) que o discurso narrativo está preocupado, sendo a "narrativização" 37 meramente a forma através da qual a narrativa, ou o artista, no caso em questão, signifique a cultura na qual estão enraizados. A noção bakhtiniana de contexto heteroglóssico ${ }^{38}$ seria um importante ponto de partida para uma análise dos códigos barthesianos que formam a narrativa e em cujas decodificações o leitor/espectador confronta os sentidos de uma cultura, enraizados em um tempo e lugar. O discurso narrativo é, portanto, o sentido da significação cultural, e é somente através da aceitação de um contexto particular que qualquer sentido universal é gerado.

IV

As mais sérias alegações de Bordwell contra a intepretação encontram em seu ataque as teorias SLAB que, ele sente, são a base para a maior parte das

\footnotetext{
${ }^{37}$ Tom Gunning acrescenta esta quarta categoria à "tríade de história, discurso e o ato de narrar" de Genette, tendo em conta o modo de narrar especificamente cinematográfico.

${ }^{38} \mathrm{Um}$ sentido diferente da "heteroglossia" de Bakhtin dos discursos populares, particularmente as formas carnavalescas, seria as diversas vozes de fé e crença religiosa que obviamente formavam o contexto da vida cotidiana do campo na Jutlândia, que Dreyer e Munk (em cuja peça o filme é baseado) utilizaram para contextualizar a exploração dessas questões.
} 
correntes interpretativas (1989a: 385-92). ${ }^{39}$ Definindo a poética histórica contra a teoria SLAB, critica a última por ser doutrinária, por não ser baseada em pesquisa sistemática, e por usar conceitos para construir narrativas interpretativas mais que proposições explanatórias. A tendência de Bordwell de polarizar posições é problemática e, em última instância, improdutiva. Embora os excessos da crítica baseada na teoria SLAB sejam inquestionáveis e precisem ser abandonados, devemos jogar o bebê juntamente com a água suja? As teorias SLAB (não os excessos críticos provenientes delas) possuem insights sobre a sociedade, história, cultura e representação que beneficiariam qualquer tentativa de análise e interpretação de textos. O próprio Bordwell compreende que desistir das práticas de interpretação seria empobrecer os estudos de cinema (1989b: 258). Sem a interpretação, a poética histórica também seria inadequada. Por outro lado, com ela, não somente a poética histórica é definitivamente enriquecida, mas também sua análise da forma e do estilo, em termos históricos, pode ser completa, como Bakhtin sugere, se também se dirigir a questões de determinação cultural, formação ideológica e suas várias manifestações. Se Bordwell reformular sua ideia de interpretação e incorporar nela a concepção de história bakhtiniana e uma concepção de narrativa bakhtiniana-barthesiana, como sugerido neste capítulo, então o projeto de poética histórica, com a interpretação plenamente absorvida dentro dele, tornar-se-ia definitivamente um curso mais promissor e frutífero para os estudos de cinema seguirem. ${ }^{40}$ Isso envolveria uma radical revisão de sua noção central de construção e sentido e sua oposição polarizada à interpretação. Para começar, deveria reinserir a noção tradicional de hermenêutica. A definição de interpretação de Ricouer como a de "decifrar o sentido oculto no aparente, um desdobramento dos níveis de sentido implícitos no sentido literal" (1980: 245, citado por Bordwell em 1989b: 2) pode operar como uma forma de observar que

\footnotetext{
${ }^{39}$ Ver nota 5 para detalhes.

${ }^{40}$ Bordwell considera isso ao final de Making meaning (273-4) e no parágrafo conclusivo da "Poética Histórica do Cinema" (p. 392): "A esse respeito, a poética histórica se torna não um método, mas um modelo de pesquisa básica em relação ao cinema".
} 
os sentidos explícitos e referenciais contêm dentro deles sentidos implícitos, sintomáticos. E com o sentido sendo observado como embutido na história e na cultura, formas culturais de representação seriam carregadas de significados que, doutro modo, não são vistos por Bordwell como relevantes para a poética histórica, sendo banidos para o reino polarizado da interpretação. Portanto, para realizar o potencial de sua proposta de revitalização do campo de estudos com a poética histórica, Bordwell deve confrontar as contradições e tensões e não reformular a interpretação com a poética histórica, mas vitalizar a última com os valores e benefícios da primeira. 


\section{Referências Bibliográficas}

ALLEN, Richard. "On narrative comprehension." Artigo apresentado na SCS Conference, Ottawa (Maio de 1997)

BAKHTIN, Mikhail. 1986a. "Response to a question from the Novy Mir Editorial Staff." In: Bakhtin 1986b.

. Speech Genres and Other Late Essays. Trans. Vern W. McGee. Austin: University of Texas Press: $1986 \mathrm{~b}$.

. The dialogic imagination: four essays. Trans. Caryl Emerson and

Michael Holquist. Austin: University of Texas Press, 1994 [1981]. and P. N. Medvedev. The formal method in literary scholarship: a critical introduction to sociological poetics. Trans. Albert J. Wehrle. Baltimore/Londres: Johns Hopkins University Press, 1978.

BARTHES, Roland. S/Z. Trans Richard Miller. Nova York: Hill and Wang, 1994 [1974].

BAZIN, Andre. "Evolution of the language of the cinema". In: What Is Cinema? Org. e Trad. Hugh Gray. Berkeley/Los Angeles/Londres: University of California Press. 1967.

BORDWELL, David. The films of Carl Theodor Dreyer. Berkeley, Los Angeles, and Londres: University of California Press, 1981. $\overline{1985 .}$ 1985. Narration in the fiction film. Madison: University of Wisconsin Press, "Historical poetics of cinema". In: the cinematic text: methods and approaches. Ed. R. Barton Palmer. Nova York: AMS Press, 1989a. pp. 369-98. Making meaning: Inference and rhetoric in the interpretation of cinema. Cambridge/Londres: Harvard University Press, 1989b. , Janet STAIGER, and Kristin THOMPSON (orgs.). The classical Hollywood

cinema: film style and mode of production to 1960. Nova York: Columbia University Pres, 1985.

CARNEY, Raymond. Speaking the language of desire. Cambridge/Nova York: Cambridge University Press, 1989.

DREYER, Carl. "A little on film style." In: Dreyer in Double Reflection, Trad. Carl Th. Dreyer's Writings About the Film (Om Filmen). Org. Donald Skoller. Nova York: Dutton, 1973 [1943].

GAUT, Berys. "Making sense of films: neoformalism and its limits". Forum for Modern Language Studies, 1995, 3 1, 1: 8-23.

GENETTE, Gerard. Narrative discourse: an essay in method. Trans. Jane E. 
Lewin. Ithaca: Cornell University Press, 1993 [1980].

GUNNING, Tom. "Theory and History: narrative discourse and the narrator System". In: D. W. Griffith and the origin of American narrative film. Urbana: University of Illinois Press, 1991.

HALL, Stuart. 1972. "The determinations of newsphotographs" Working Papers in Cultural Studies 3: 65.

LESAGE, Julia. "S/Z and the rules of the game". In: Movies and Methods Vol. II. (Org.). Ed. Bill Nichols. Berkeley/ Los Angeles/Londres: University of California Press, 1985.

RICOEUR, Paul. "Existence and Hermeneutics". In: Contemporary Hermeneutics: Hermeneutics as method, philosophy, and critique. Londres: Routledge and Kegan Paul, 1980.

SCHATZ, Thomas. Hollywood Genres: Formulas, Filmmaking, and the Studio System. Nova York: Random House, 1981.

STAM, Robert. Subversive Pleasures: Bakhtin, cultural criticism, and film. Baltimor/Londres: Johns Hopkins University Press, 1989.

, Robert Burgoyne, and Sandy Flitterman-Lewis.. New Vocabularies in Film Semiotics. Londres/Nova York: Routledge, 1992.

TODOROV, Tzvetan. Theories of the Symbol. Trad. Catherine Porter. Ithaca: Cornell University Press, 1982.

TURVEY, Malcolm. "Seeing Theory: On Perception and Emotional Response in Current Film Theory". In: Film Theory and Philosophy. Orgs. Richard ALLEN and Murray SMITH. Oxford: Clarendon Press., 1997, 43 1-57.

WILLIAMS, Raymond. The Sociology of Culture. New York: Schocken Books, 1982.

WILSON, George. "On Film Narrative and Narrative Meaning". In: Film Theory and Philosophy. Org. Richard ALLEN and Murray SMITH. Oxford: Clarendon Press, 1997. 